\title{
PERAN MEDIA SOSIAL "FACEBOOK" JELANG PEMILIHAN UMUM KEPALA DAERAH TAHUN 2017 DI KABUPATEN ACEH JAYA
}

\author{
Aminah \\ Program Studi Ilmu Komunikasi, Universitas Teuku Umar \\ Email: Aminahaneukpanga@gmail.com
}

\begin{abstract}
This study aims to explain the role of Social Media "Facebook" and its impacts ahead of the elections of regional heads in 2017 in Aceh Jaya district. Data required in this study was obtained through literature and field research. The research literature is done by reading textbooks, legislation, and other reading materials related to this research. While the field research conducted by interviewing informants. The results showed that social media "Facebook" very effective way of delivering a variety of things including the introduction of a track record as well as the vision and mission of the future leaders of Aceh Jaya fore. Campaigns that use social networking "Facebook" more influential than campaigns that are only focused on the delivery of any information or content (in the sense of simply using billboard and his card only). In the use of social media "Facebook" there are various impacts. There are two impacts: the effect of positive and negative impacts. The positive impact of the using social media "Facebook" in the election of Aceh Jaya, namely (1) the establishment of kinship fellow Team (timses) of each candidate, (2) can foster public participation in politics (3) provides information on the dynamics of the election in Aceh Jaya (4) to introduce the candidates (5) to introduce the vision and mission of the candidates. As for the negative impact of (1) to attack each other between supporters and supporters Irfan TB Well yahGam (2) Dropping Party Opposition.
\end{abstract}

Keywords: Role of Facebook, Political Communication and Election

\section{PENDAHULUAN}

Komunikasi politik (political communication) merupakan komunikasi yang melibatkan aktor-aktor politik serta menyampaikan pesan-pesan politik, atau berkaitan dengan kekuasaan, pemerintahan, dan kebijakan pemerintah. Di Indonesia pada saat ini momen-momen politik begitu banyak terjadi yang melibatkan seluruh masyarakat untuk ikut berpartisipasi di dalamnya seperti pada pemilihan umum secara langsung anggota legislatif (Pileg), pemilihan langsung Presiden (Pilpres) dan pemilihan langsung kepala daerah (Pemilukada). Momen-momen politik tersebut meniscayakan lahirnya berbagai bentuk komunikasi politik. Banyak hal yang dapat digunakan sebagai alat komunikasi politik salah satunya yaitu Media (Aminah, 2016:175).

Pemilukada merupakan ajang pemilihan yang sering kali dijadikan sebagai pesta demokrasi rakyat yang juga selalu dinantikan oleh masyarakat di setiap daerah. Melalui adanya partisipasi masyarakat, diharapkan pemilukada ini dapat berjalan secara Langsung, Umum, Bebas, Rahasia, jujur dan adil. Menjelang pemilukada, Kabupaten Aceh Jaya tahun 2017 ada begitu banyak atribut-atribut kampanye yang bertebaran diseluruh wilayah Aceh Jaya dimulai dari Kaki Gunong Gurutee hingga ke Wilayah Pasi Raya yang disebarkan oleh tim pemenangan. Berbagai upaya dilakukan oleh pihak tim pemenangan atau Tim Sukses (TIM SES) untuk memperkenalkan para calon Bupati (Cabup) dan calon Wakil Bupati (Cawabup) kepada masyarakat melalui percetakan spanduk, media sosial, baliho, kaos-kaos, bendera, kartu nama calon, bendera dan lain sebagainya. 
Seiring perkembangan informasi teknologi yang semakin besar, inovasi dan kreativitas dari setiap sudut juga semakin meningkat. Hal ini terlihat bahwa dalam hal kampanye, pihak kandidat pasangan Cabup dan Cawabup tidak hanya dilakukan melalui spanduk dan kartu nama dan dalam bentuk pemberian sembako. Namun, para TIM SES mulai memperkenalkan Cabup dan Cawabup melalui media massa khususnya media sosial "Facebook". Media sosial "Facebook" menjadi salah satu sarana yang digunakan oleh para TIM SES serta para Cabup dan Cawabup untuk mempromosikan visi misi calon kepala daerah kepada masyarakat melalui Internet. Media sosial "Facebook" pada saat ini telah mendominasi kehidupan masyarakat untuk mendapatkan melakukan interaksi antara sesame masyarakat.

Media, dalam komunikasi politik memiliki kemampuan untuk mempengaruhi opini dan prilaku pemilih (masyarakat) melalui informasi, reportase, ulasan dan investigasi yang disajikan. Beberapa ahli komunikasi politik memang mengemukakan bagaimana peran media dalam proses politik. Dalam konteks politik modern, media massa tidak hanya menjadi bagian yang integral dari politik, tetapi media massa menjadi sentral dalam politik (Pawito, 2009:91).

Menjelang pemilukada di Kabupaten Aceh Jaya, para pasangan Cabup dan Cawabup bersama dengan Partai dan tim penenangannya sendiri mulai marak melakukan kampanye serta menyampaikan visi dan misi dari setiap calon. Adapun yang menjadi Cabup dan Cawabup di Kabupaten Aceh Jaya adalah

1. Pasangan Drs. H. T. Irfan TB dan Tgk. Yusri.S (Yang diusung oleh Partai Aceh dan Partai Demokrat dan partai pendukung yaitu Gerindra, PKS, PDIP, PAN, Nasdem, PPP, Hanura, PKB dan Partai Bulan Bintang).

2. Ir. Junaidi (Yah Gam) dan Bustami Syarbini, S.T (Yang diusung oleh Partai Golkar, PNA, PDA, PKPI dan partai pendukung yaitu Partai Idaman).

Dari kedua pasangan Cabup dan Cawabup Kabupaten Aceh Jaya ini menarik untuk dikaji dalam hal peran media kampanye yang dilakukan oleh masing-masing pasangan Cabup dan Cawabup menjelang pemilukada serentak 2017. Kajian ini lebih memfokuskan kepada bagaimana peran media sosial "Facebook" dan dampak dari media sosial "Facebook" jelang pemilihan umum kepala daerah tahun 2017 di kabupaten aceh jaya?

\section{KERANGKA TEORI}

Dalam kajian ini, penulis menggunakan teori-teori yang relevan dari berbagai literatur khususnya tentang Komunikasi, Unsur-Unsur dalam Komunikasi, komunikasi politik dan kampanye.

\section{Komunikasi}

Istilah "komunikasi" (Bahasa Inggris "communication") berasal dari bahasa Latin "communicates" atau "communication" atau "cummunicare" yang berarti "berbagi" atau "menjadi milik bersama". Dengan demikian, kata komunikasi menurut kamus bahasa mengacu pada suatu upaya yang bertujuan untuk mencapai kebersamaan (Riswandi, 2009: 1). Joseph A.Devito (1978) dalam bukunya "Communicologi: An Introduction to The Study of Communication" menjelaskan bahwa komunikasi adalah kegiatan yang dilakukan seseorang atau lebih dari kegiatan menyampaikan dan menerima pesan komunikasi yang terganggu keributan, dalam suatu konteks, bersama dengan beberapa efek yang timbul dari kesempatan arus balik (Lubis, 2005:10). Menurut Bernard Berelson dan Gary A. Steiner komunikasi merupakan suatu proses penyampaian informasi, gagasan, emosi, keahlian, dan lain-lain melalui penggunaan simbol-simbol seperti kata-kata, gambar, angka-angka, dan 
lainnya. Sedangkan menurut Weaver Komunikasi adalah seluruh prosedur melalui mana pikiran seseorang dapat mempengaruhi pikiran orang lainnya (Riswandi, 2009: 2).

Shannon dan Weaver (1949) bahwa komunikasi adalah bentuk interaksi manusia yang saling pengaruh mempengaruhi satu sama lainnya, sengaja atau tidak sengaja. Komunikasi tidak terbatas pada bentuk komunikasi menggunakan bahasa verbal, tetapi juga dalam hal ekspresi muka, lukisan, seni, dan teknologi. Oleh karenanya, jika kita berada dalam suatu situasi berkomunikasi, maka kita memiliki beberapa kesamaan dengan orang lain, seperti kesamaan bahasa atau kesamaan arti dari simbol-simbol yang digunakan dalam berkomunikasi (Cangara, 2007: 19-20).

\section{Unsur-Unsur Komunikasi}

Terdapat beberapa macam pandangan tentang banyaknya unsur atau elemen yang mendukung terjadinya komunikasi. Aristoteles, ahli filsafat Yunani Kuno dalam bukunya Rhetorica menyebut bahwa suatu proses komunikasi cukup didukung oleh tiga unsur yang mendukungnya, yakni siapa yang berbicara, apa yang dibicarakan dan siapa yang mendengarkan (Cangara 2006:21). Awal tahun 1960-an David K. Berlo membuat formula komunikasi yang lebih sederhana. Formula itu dikenal dengan nama "SMCR", yakni: Source, Message, Channel dan Receiver. Kemudian Charles Osgood, Gerald Miller dan Melvin L. De Fleur menambahkan lagi unsur efek dan feedback. Perkembangan terakhir adalah munculnya pandangan dari Joseph de Vito, K. Sereno dan Erika Vora yang menilai faktor lingkungan merupakan unsur yang tidak kalah penting dalam proses komunikasi.

Dari beberapa pendapat di atas, dapat disimpulkan bahwa unsur-unsur komunikasi adalah sebagai berikut:

1. Pengirim Pesan atau Sumber. Pengirim pesan adalah individu yang mengirim pesan. Dalam komunikasi antarmanusia, sumber bisa terdiri dari satu orang, tetapi bisa juga dalam bentuk kelompok misalnya partai, organisasi, atau lembaga.

2. Pesan. Pesan adalah sesuatu yang disampaikan pengirim kepada si penerima. Pesan ini dapat berupa verbal maupun nonverbal. Pesan secara verbal dapat secara tertulis maupun lisan. Pesan nonverbal dapat berupa isyarat, gerakan badan, ekspresi muka, dan nada suara.

3. Saluran atau Media. Saluran atau media adalah jalan/alur yang dilalui pesan dari si pengirim kepada si penerima. Saluran yang biasa dalam komunikasi adalah gelombang cahaya dan gelombang suara yang dapat kita lihat dan dengar. Media yang dimaksud di sini adalah alat yang digunakan untuk memindahkan pesan dari sumber kepada penerima.

4. Penerima Pesan. Penerima pesan adalah pihak yang menganalisis dan menginterpretasikan isi pesan yang diterimanya. Penerima bisa terdiri dari satu orang atau lebih, bisa dalam bentuk kelompok, partai atau negara. Penerima biasa disebut dengan berbagai istilah, seperti khalayak, sasaran, komunikan, atau dalam bahasa Inggris disebut audience atau receiver.

5. Pengaruh. Pengaruh atau efek adalah perbedaan antara apa yang dipikirkan, dirasakan dan dilakukan oleh penerima sebelum dan sesudah menerima pesan. Pengaruh ini bisa terjadi pada pengetahuan, sikap dan tingkah laku seseorang.

6. Tanggapan Balik. Ada yang beranggapan bahwa umpan balik sebenarnya adalah salah satu bentuk daripada pengaruh yang berasal dari penerima. Akan tetapi sebenarnya umpan balik juga berasal dari unsur lain seperti pesan dan media, meski pesan belum sampai kepada penerima.

7. Lingkungan. Lingkungan atau situasi ialah faktor-faktor tertentu yang dapat mempengaruhi jalannya komunikasi. Faktor ini dapat digolongkan atas empat 
macam, yakni lingkungan fisik, lingkungan sosial budaya, lingkungan psikologis, dan dimensi waktu.

\section{Komunikasi Politik}

Komunikasi politik adalah komunikasi yang diarahkan kepada pencapaian suatu pengaruh yang melakukan sedemikian rupa, sehingga masalah yang dibahas oleh jenis kegiatan komunikasi ini, dapat mengikat semua warganya melalui suatu sanksi yang ditentukan bersama oleh lembaga-lembaga politik (Astrid, S. Soesanto, 1980:2). Mengenai komunikasi politik ini (political communication) Kantaprawira (1983:25) memfokuskan pada kegunaanya, yaitu untuk menghubungkan pikiran politik yang hidup dalam masyarakat, baik pikiran antar golongan, institusi, asosiasi, ataupun sektor kehidupan politik masyarakat dengan sektor kehidupan politik pemerintah.

Pendapat lain tentang komunikasi politik juga disampaikan oleh Lasswell (dalam Varma, 1995:258) memandang orientasi komunikasi politik telah menjadikan dua hal sangat jelas: pertama, bahwa komunikasi politik selalu berorientasi pada nilai atau berusaha mencapai tujuan; dan kedua, bahwa komunikai politik bertujuan menjangkau masa depan dan bersifat mengantisipasi serta berhubungan dengan masa lampau dan senantiasa memperhatikan kejadian masa lalu.

Selanjutnya Komunikator politik Menurut Nimmo, salah satu ciri komunikasi ialah bahwa orang jarang dapat menghindari dan keturutsertaan. Hanya dihadiri dan diperhitungkan oleh seorang lain pun memiliki nilai pesan. Dalam arti yang paling umum kita semua adalah komunikator, begitu pula siapa pun yang dalam setting politik adalah komunikator politik (2000:28). Berdasarkan hal tersebut, jelas bahwa para komunikator harus diidentifikasi serta kedudukan mereka di dalam masyarakat harus ditetapkan. Untuk keperluan ini Nimmo (2000:30) mengidentifikasi tiga kategori politikus, yaitu yang bertindak sebagai komunikator pilitik, komunikator profesional dalam politik, dan aktivis atau komunikator paruh waktu (part time).

\section{Kampanye}

Pfau dan Parot (Venus, 2004:8) memberikan pengertian terkait Kampanye sebagai berikut: "campaign is conscious, sustained and incremental process designed to be implemented over a specified periode of time for the purpose of influencing a specified Audience" (kampanye adalah suatu proses yang dirancang secara sadar, bertahap dan berkelanjutan yang dilaksanakan pada rentang waktu dengan tujuan mempengaruhi masyarakat sebagai sasaran yang telah ditetapkan). Sementara menurut Kotler dan Roberto (1989) dalam Cangara (2009:284) kampanye adalah sebagai berikut: "a campaign is an organized effort conducted by one group (the change agent) which intends to persuade others (the target adopters), to accept, modify, or abandon certain ideas, attitudes, practices and behavior". (Kampanye ialah sebuah upaya yang dikelola oleh satu kelompok, (agen perubahan) yang ditujukan untuk mempersuasi target sasaran agar bisa menerima, memodifikasi atau membuang ide, sikap dan perilaku tertentu).

Berdasarkan defenisi tersebut maka setiap aktifitas kampanye setidaknya harus mengandung empat hal yakni: (1) Tindakan kampanye yang ditujukan untuk menciptakan efek atau dampak tertentu, (2) Jumlah masyarakat sebagai sasaran yang besar, (3) Biasanya dipusatkan dalam kurun waktu tertentu, dan (4) Melalui serangkaian tindakan komunikasi yang terorganisasi. Selain keempat hal tersebut, kampanye juga memiliki karakteristik lain, yaitu sumber yang jelas, yang menjadi penggagas, perancang, penyampai sekaligus penanggung jawab suatu produk kampanye, sehingga setiap individu yang menerima pesan kampanye dapat mengidentifikasi dan mengevaluasi kredibilitas sumber pesan setiap saat. 


\section{Metode}

Metode yang digunakan dalam penelitan ini yaitu metode kualitatif deskriptif. Teknik pengumpulan data dilakukan dengan dua cara yaitu studi kepustakaan dan ke lapangan. Studi kepustakan dilakukan dengan mencari berbagai referensi yang mendukung terhadap kasus yang diangkat. Sedangkan ke lapangan dengan observasi serta melihat dan memantau melalui akun media sosial "Facebook" pribadi penulis terkait fenomena kampanye yang sedang marak terjadi di Kabupaten Aceh Jaya menjelang pemilukada 2017.

\section{Pembahasan dan Analisis}

Analisis dalam kajian ini berhubungan dengan pemanfaatan media sosial "Facebook" oleh para aktor politik dalam hal ini TIM SES sebagai suatu cara untuk mempengaruhi masyarakat Kabupaten Aceh Jaya untuk memilih salah satu kandidat yang didukungnya. Fokus kajian adalah peran media sosial "Facebook" serta dampak dari pemanfaatan media sosial "Facebook" jelang pemilikada di Kabupaten Aceh Jaya.

\section{Peran Media Sosial "Facebook" dalam Pemilukada Aceh Jaya}

Menjelang pemilihan umum yang serentak dilakukan di beberapa daerah yang ada di Indonesia pada tanggal 15 Februari 2017, media sosial "Facebook" dijadikan sebagai ajang untuk berkampanye. Semakin dekat waktu pemilu dilaksanakan, semakin memanas kondisi politik yang beredar didalam suatu masyarakat, apalagi ada pendukung yang berbeda dalam satu group diskusi di media Sosial "Facebook". Tentu disini akan ada hal-hal yang pada akhirnya saling menyerang antara satu pendukung dengan pendukung yang lainnya. Media sosial "Facebook" sangat efektif untuk menyampaikan berbagai hal termasuk dalam hal memperkenalkan rekam jejak serta visi dan misi dari sang calon pemimpin Aceh Jaya kedepan.

Kalau kita perhatikan kebanyakan kampanye politik yang berupa iklan baik di TV, media cetak atau jalanan berupa spanduk dan baliho, semuanya ditujukan kepada orang yang melihat langsung iklan-iklan tersebut, yang sering dibicarakan adalah isi iklan tersebut. Bagaimana caranya agar isi iklan dapat mempengaruhi pilihan semua orang yang melihat iklan yang dipajangkan. Dengan asumsi ini, logika yang digunakan adalah: jika iklan dilihat banyak orang, maka banyak pula orang yang terpengaruhi. Sehingga spot iklan yang ditengarai dilihat banyak orang semakin mahal pula harganya. Logika ini merupakan logika individu. Dimana yang utama terjadi disini adalah interaksi antara masing-masing individu dengan materi iklan.

Selain logika individu juga terdapat logika jejaring yaitu orang dipengaruhi bukan oleh materi kampanye secara langsung akan tetapi oleh orang lain yang telah melihat kampanyenya atau belum. Dengan kata lain, pengaruh sosial lebih berperan dibanding pengaruh materi atau isi kampanye. Konsekuensi dari logika jejaring ini adalah kita tidak cukup memperhatikan seberapa persuasif sebuah kampanye bagi orang, tetapi juga memikirkan kemungkinan orang saling berbagi sehingga kampanye tersebut menyebar dari orang ke orang dan seterusnya. Jadi jumlah yang relevan disini bukan jumlah orang yang melihat langsung sebuah iklan, tapi sebarapa menular kampanye tersebut sehingga mencapai banyak orang yang mungkin tak pernah melihat materi kampanye.

Kampanye yang memanfaatkan jejaring sosial "Facebook" lebih berpengaruh daripada kampanye yang hanya fokus pada penyampaian informasi atau konten saja. Penyebaran perubahan perilaku cenderung terjadi antar teman dekat yang mungkin dibarengi dengan interaksi tatap muka dan membuat diskusi-diskusi dengan berbagai kalangan di dalam kelompok masyarakat. Sehingga lebih efektif dalam melakukan kampanye melalui media sosial "Facebook". 


\section{Dampak Media Sosial "Facebook" dalam Pemilukada Aceh Jaya}

Dampak merupakan pengaruh kuat yang mendatangkan akibat. Berbicara mengenai dampak, tentuk saja akan ada dampak dari sisi positif dan dampak dari segi negatifnya.

\section{Dampak Positif}

Dampak positif dari penggunaan media sosial "Facebook" dalam pemilukada Aceh Jaya adalah sebagai berikut:

a. Terjalinnya Tali Persaudaraan Sesama TIM SES dari Masing-masing Pasangan Calon

Melalui adanya media sosial "Facebook" akan terjalinnya tali persaudaraan antar sesama TIM SES dan Tim relawan dari masing-masing Pasangan Calon. Hal ini seperti yang terjadi pada pendukung Irfan TB, dimana para pendukungnya yang berada di wilayah Kecamatan Jaya dapat saling berinteraksi dengan pihak pendukung Irfan TB yang berada di wilayah Kecamatan Teunom. Hal yang sama juga terjadi pada kelompok pendukung Yah Gam, pihak pendukungnya sama-sama membuat kesepakatan mengenai tentang penjadwalan kampanye yang akan dilaksanakan disuatu kecamatan atau tempat yang akan diadakan kampanye. Sehingga kerja sama, persaudaraan dan ikatan keluarga akan sangat terlihat pada kondisi ini. Sesama pendukung saling memberikan pendapatnya mengenai hal yang sedang dibahas dan bahkan saling menanggapi antara satu dengan yang lainnya.

Selain saling berinteraksi antar sesama pendukung, pihak pendukung juga memberikan bantuan secara moril dan materil untuk pasangan Calon Bupati yang di dukungnya. Hal ini seperti yang terjadi pada pasangan Calon Bupati No Urut 2 (Yah Gam), salah satu TIM SES (YS) mengakui bahwa mereka memberikan segala yang dimilikinya "Uang dan Tenaga" untuk memenangkan TIM Yah Gam. "Saya sendiri memberikan satu ekor lembu untuk acara kampanye yang akan dilaksanakan di Gampong Keudee Panga. Tidak hanya itu, para pendukung dan simpatisan Yah Gam yang lainnya juga ikut menyumbang baik dalam bentuk materil maupun tenaganya" (Wawancara, 20 Januari 2017).

Terbentuknya ikatan tali persaudaraan dan kekeluargaan dalam suatu kelompok juga disebabkan oleh adanya rasa keinginan untuk memenangkan salah satu kandidat yang mereka usung secara bersama-sama demi memajukan Aceh Jaya kedepannya. Kesamaan pendapat dan pemikiran menyebabkan salah satu masyarakat tetap mendukung sepenuhnya terhadap calon yang mereka unggulkan. Dengan adanya kekompakan dalam suatu ikatan tali persaudaraan membuat suatu kelompok akan semakin kuat.

\section{b. Dapat Menumbuhkan Partisipasi Masyarakat dalam Berpolitik}

Dengan adanya kemajuan teknologi informasi terutama dalam kemajuan dalam menggunakan media sosial "Facebook" dapat menumbuhkan kesadaran masyarakat khususnya di Kabupaten Aceh Jaya untuk membuhkan dan membangun partisipasi masyarakat dalam berpolitik. Melalui adanya penggunaan media sosial "Facebook" masyarakat dapat mengikuti setiap informasi yang dibagikan di Time Linenya untuk selalu memantau mengenai perkembangan-perkembangan tentang politik yang sedang terjadi. Dari sebelumnya para masyarakat belum mengenal sosok calon pemimpinnya, melalui media sosial "Facebook" yang dibagikan oleh temantemannya yang lain dapat dilihat tentang bagaimana sosok pemimpin yang akan dipilih nantinya. Apalagi masyarakat yang baru bergabung dengan beberapa TIMSES tentu mereka akan mengikuti setiap pemberitaan yang sedang berlangsung di Kabupaten Aceh Jaya.

Selain itu, masyarakat yang masih apatis terhadap politik, apabila melihat komentar-komentar yang dilontarkan oleh beberapa orang yang bergabung terkadang juga membuat mereka geram dengan komentar-komentar tersebut. Sehingga dengan sendirinya partisipasi masyarakat dalam berpolitik mulai terbangun dengan 
sendirinya. Hal ini seperti yang dijelaskan oleh (KM) bahwa "saya sebenarnya tidak begitu tertarik dengan dunia politik, karena bagi saya politik itu kayaknya lebih banyak yang nggak baiknya daripada baiknya. Kadang-kadang saya geram juga melihat postingan-postingan di Facebook itu, kadang mereka saling memfitnah dan bahkan kadang saling mengejek. Saya sering menegur mereka juga melaui komentar di dalam satu status FB orang. Itu karena udah geram kali saya lihat. Sebenarnya iya itu sudah termasuk saya sudah ikut dalam berpolitik, jadi karena itu tadi, dari satu sisi kita lihat memang ada bagusnya juga ada FB ini, kita bisa saling memberikan saransaran sesama teman kita dan kita bisa langsung ikut nimbrung dalam status FB orang tanpa harus minta ijin dulu" (Wawancara, 23 Januari 2017).

\section{c. Memberikan Informasi mengenai Dinamika Pemilukada Kabupaten Aceh Jaya}

Kegunaan media sosial "Facebook" juga sangat berpengaruh penting dang meng-Update informasi-informasi tentang pelanggaran-pelanggaran yang dilakukan oleh setiap pasangan calon Bupati dan para TIM SES-nya. Hal ini seperti pelanggaran yang dilakukan oleh pihak TIM SES pasangan Irfan TB yaitu melakukan kampanye pada masa tenang. Berikut adalah bukti pemberian informasi yang dilakukan oleh pihak Yah Gam kepada publik mengenai pelanggaran yang dilakukan oleh pihak TIM Irfan TB.
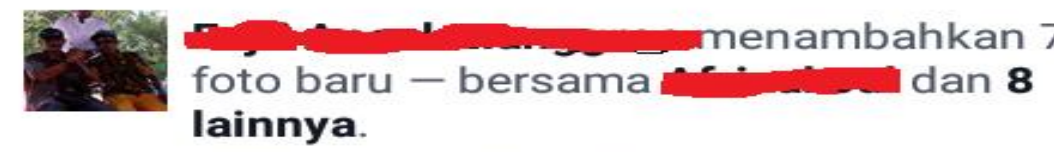

Irfan. TB-Yusri melakukan pelanggaran pilkada dengan melakukan kampanye (pertemuan) dengan masyarakat di hari tenang pada hari Minggu tanggal 12 Pebruari 2017 sekitar pukul 15.00 wib di desa Gampong baroh kec.setia bakti kab.aceh Jaya.
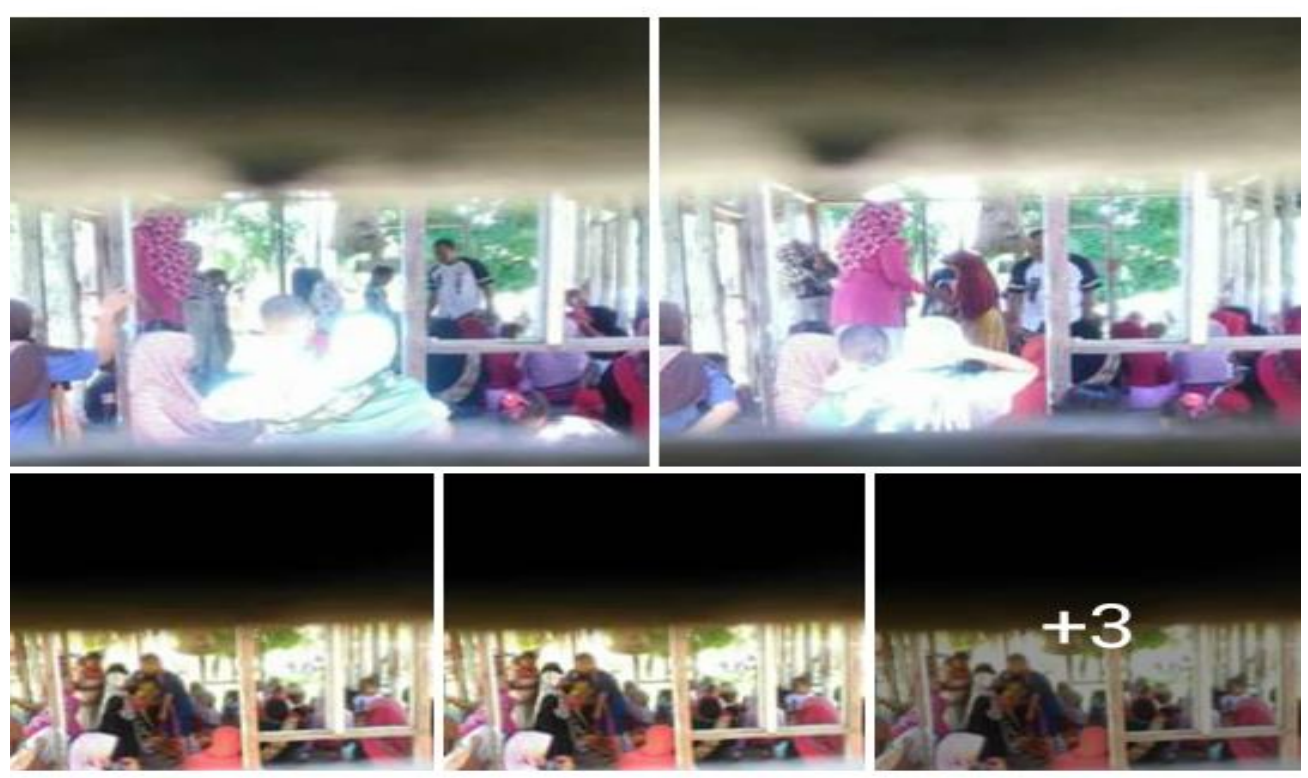

(14) $\geq<*^{\circ} 99$

79 Komentar 5 Kali Dibagikan

Gambar I. Bentuk Pemberian Informasi Tentang Pelanggaran Pemilu 
Selain pemberian informasi mengenai pelanggaran-pelanggaran yang dilakukan oleh pihak lawan, pemberian informasi yang akurat mengenai bertambahnya para TIM simpatisan yang dulunya mendukung calon yang satu kemudian berpindah dukungannya kepada TIM pendukung kedua. Hal ini seperti yang terjadi pada TIM Irfan TB, dimana adanya beberapa masyarakat yang berpindah dukungan yang dulunya mereka mendukung Yah Gam kemudian beralih mendukung TIM Irfan TB. Adapun bukti pemberian informasi tersebut dapat dilihat pada gambar berikut ini:
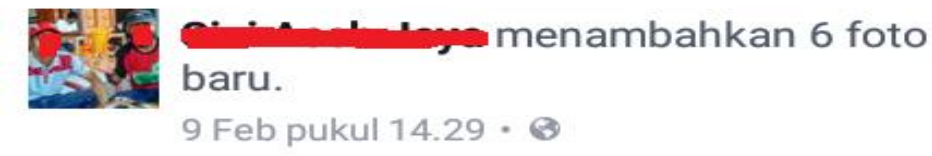

Ini lah yang terjadi setelah acara Kampanye Akbar Calon bupati dari partai Golkar di Aceh jaya,,Timses Golkar dan Timses Yahgam berbalik arah mendukung Calon Bupati nomor urut I ( satu ) T.irfan. Tb- Tgk Yusri.S

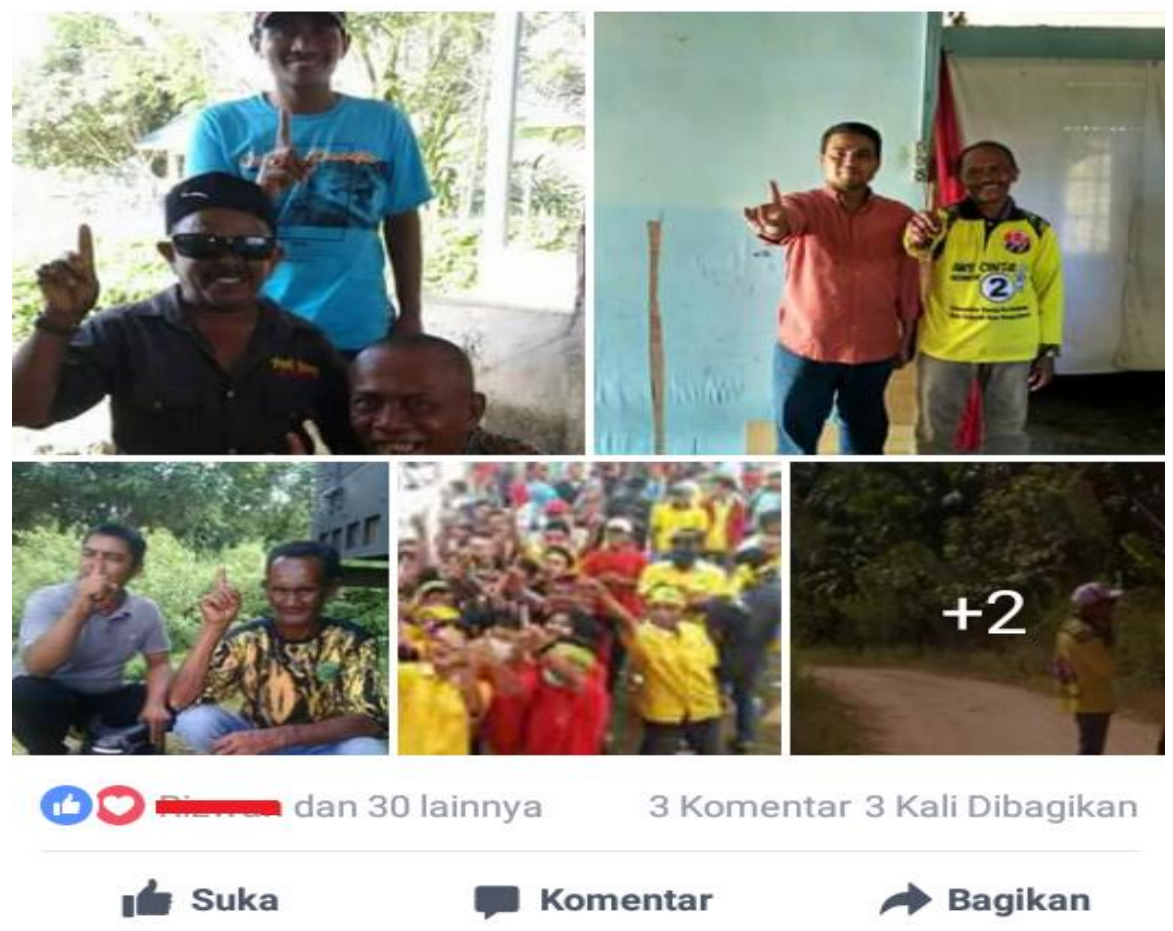

\section{Gambar II. Bentuk Pemberian Informasi Tentang Pendukung Yang Beralih Dukungannya}

Informasi merupakan suatu hal yang sangat dalah kehidupan umat manusia, manusia selalu membutuhkan tentang informasi-informasi yang terjadi di sekitarnya atau bahkan di daerah luar. Terkait hal itu, setiap ada informasi yang dilempar ke ruang publik akan dibedah bersama dan mendapat tanggapan-tanggapan dari berbagai kalangan. Dengan adanya media sosial "Facebook", masyarakat Kabupaten Aceh Jaya akan semakin mudah dalam mengikuti perkembangan dan isu-isu yang dimunculkan oleh media terutama terkait informasi tentang perkembangan pemilukada 2017. Setiap ada isu yang dimunculkan akan muncul begitu banyak tanggapan dan komentar dari berbagai kalangan terhadap isu tersebut. Sehingga 
penggunaan media sosial "Facebook" sangat efektif sebagai alat untuk memberikan perkembangan informasi mengenai dinamika pemilukada Kabupaten Aceh Jaya.

\section{d. Dapat memperkenalkan Calon Kandidat Kepada Masyarakat}

Media sosial "Facebook" sebagai suatu ajang yang dapat dimafaatkan oleh setiap orang untuk memperkenalkan diri kepada dunia luar bahkan orang secara keseluruhannya. Melaui adanya media sosial "Facebook" para kandidat yang mencalonkan diri dapat membuat review tentang riwayat hidupnya, mulai dari Namanya, pekerjaan, status pernikahan, riwat pendidikan dan berapa jumlah keluarganya dapat diterakan pada satu catatan penting di media sosial "Facebook". Dengan membuat riwat hidup tersebut, para masyarakat dapat menilai setiap kandidat yang ingin di dukungnya dan bahkan ketika memilih di hari $\mathrm{H}$-nya. Berikut adalah salah satu bentuk cara para TIM SES memperkenalkan kandidatnya kepada publik:

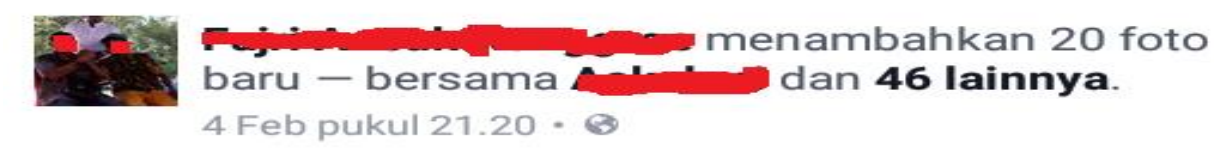

MALAM minggu 4 januari 2017 Sedang berlansung kaum ibu 2 bakar ikan dan makan bersama begitu kompak.di gampong mon mata.sedangkan bapak 2 ngopi bareng malam ini di kede pendukung yah gam. IR. JUNAIDI DAN BUSTAMI SYARBINI ST. BUKTI NYATA PEMERSATU RAKYAT ACEH JAYA. BELUM JADI BUPATI SUDAH MAMPU MENPERSATUKAN SEMUA.

INSYAALLAH SEMOGA YAH GAM adalah ses... Lanjutkan Membaca
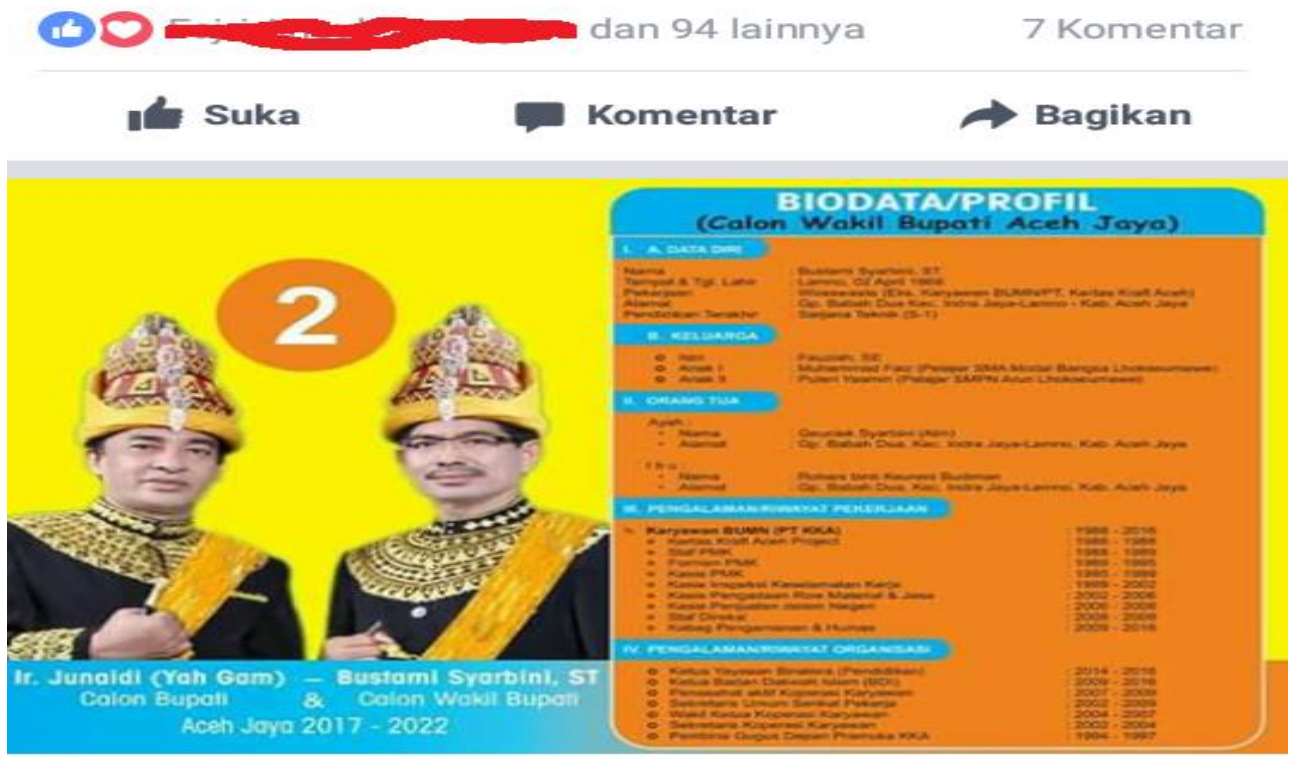

Gambar III. Bentuk Perkenalan Pasangan Calon Kepada Publik Melalui Media Sosial Facebook

Selain itu, penggunaan media sosial "Facebook" juga dapat diefektifkan oleh pihak simpatisan setiap pendukung yaitu dengan membagikan artikel yang telah dibuat oleh TIM SES. Dengan adanya para yang membagikan artikel tersebut dengan sendirinya juga akan semakin banyak mendapatkan dukungan terutama dikalangan masyarakat yang masih "terombang-ambing" dalam menentukan pilihannya. Berikut adalah salah satu contoh artikel yang dibagikan oleh pihak TIM SES dan para TIM 
simpatisan untuk menarik perhatian masyarakat agar dipilih sebagai Bupati Aceh Jaya pada tanggal 15 Februari 2017.
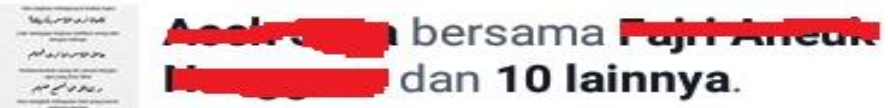

4 Feb pukul $22.41 \cdot 21$

https://klikkabar.com/2017/02/02/mengenal-lebihdekat-pasangan-calon-bupati-aceh-jaya-yah-gambustami/

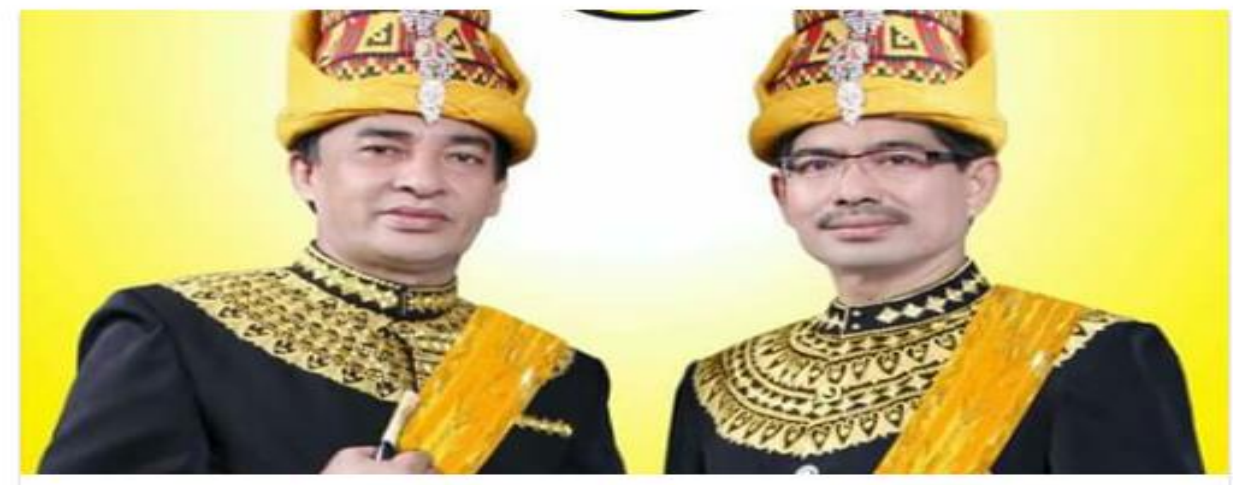

Mengenal Lebih Dekat Pasangan Calon Bupati Aceh Jaya, Yah Gam-Bustami | Klikkabar.com klikkabar.com

Gambar IV. Bentuk Perkenalan Pasangan Calon Kepada Publik Melalui Media Sosial Facebook

Hal yang sama seperti yang yang dilakukan oleh pihak Yah Gam, pihak Irfan TB juga melakukan pengenalan melalui media sosial "Facebook", berikut adalah buktinya: 


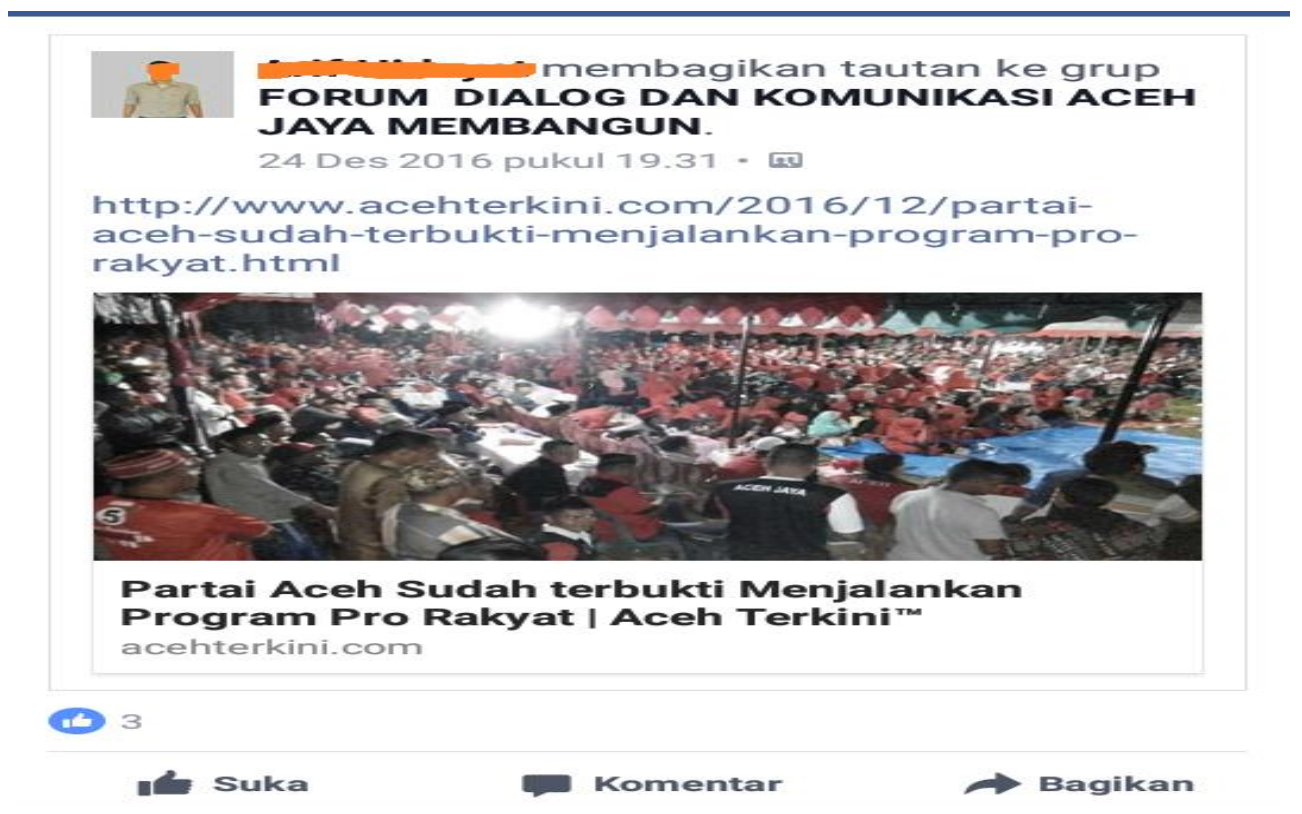

\section{Gambar V. Bentuk Perkenalan Pasangan Calon Kepada Publik Melalui Media Sosial Facebook}

e. Dapat Memperkenalkan Visi dan Misi Calon Kandidat Kepada Masyarakat

Penggunaan media sosial "Facebook" yang beredar saat ini juga difungsikan untuk kepentingan politik yaitu untuk memperkenalan visi dan misi dari setiap pasangan calon. Pemanfaatan media sosial "Facebook" ini merupakan satu langkah yang membuat masyarakat suatu daerah semakin maju. Karena untuk mendapatkan berita yang sedang dia ikuti tidak perlu menunggu lama. Setiap detik, menit, dan jam berita terus diperbaharui. Setiap orang dapat mengikutinya tanpa terkecuali bagi setiap pengguna media sosial "Facebook".

Penggunaan media sosial "Facebook" dapat membantu para TIM SES dan simpatisan untuk memperkenalkan visi dan misi kandidat yang di dukungnya. Melalui akun media sosial "Facebook"-nya setiap para TIM SES dan simpatisan dapat membagikan berita atau info mengenai visi dan misi yang ingin disampaikan kepada masyarakat pada umumnya.

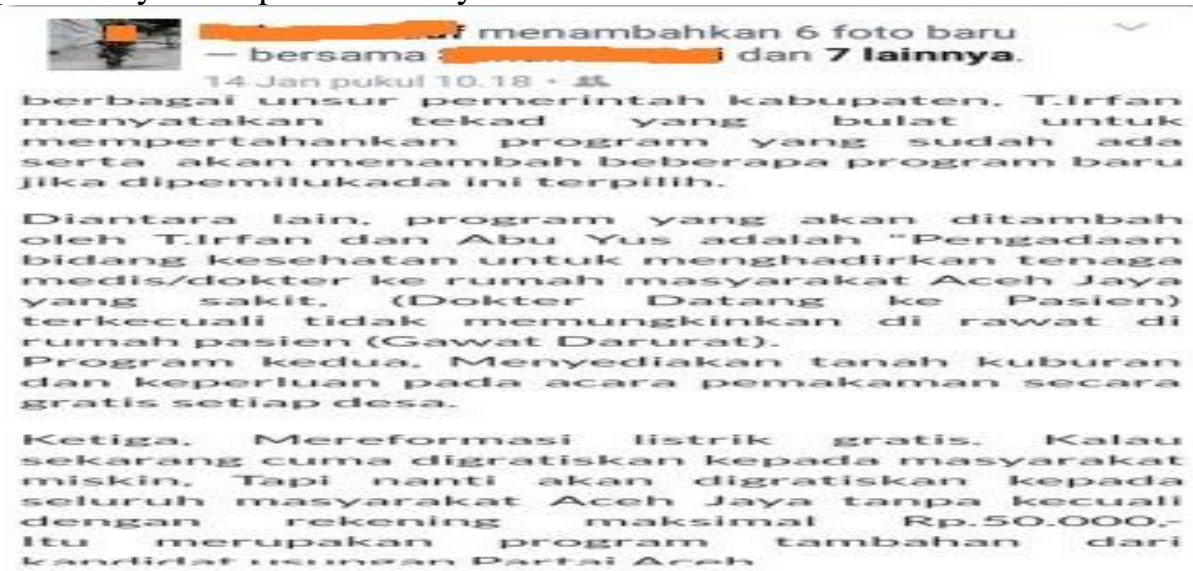

\section{Gambar VI. Bentuk Perkenalan VISI dan MISI Pasangan Calon Kepada Publik Melalui Media Sosial Facebook}

Hal yang sama juga terjadi pada pasangan Yah Gam, berikut adalah bukti visi dan misi Yah Gam yang disampaikan di media sosial "Facebook": 


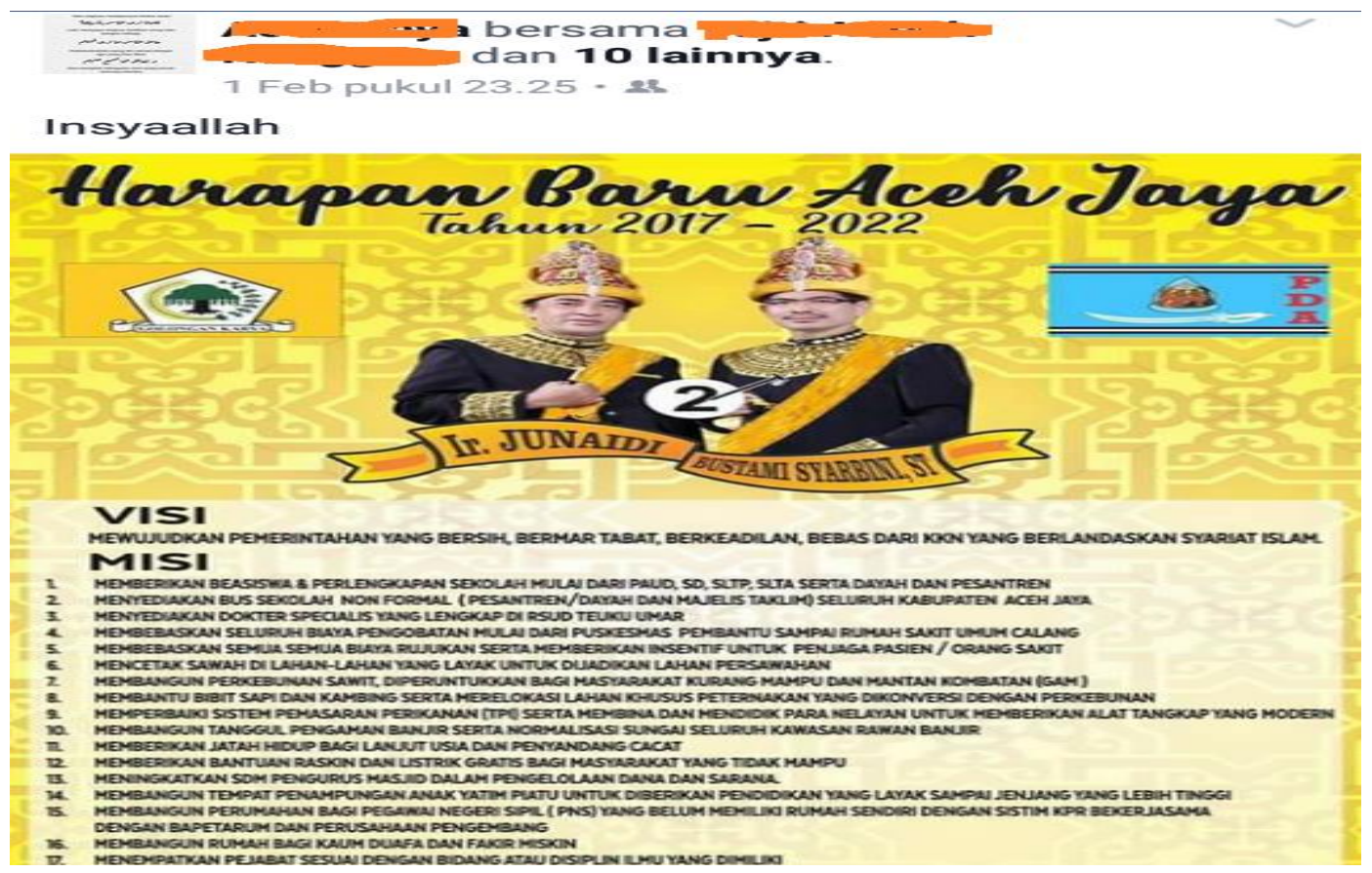

Gambar VII. Bentuk Perkenalan VISI dan MISI Pasangan Calon Kepada Publik Melalui Media Sosial Facebook

Berdasarkan hasil pengamatan dan wawancara yang dilakukan dilapangan serta pemantauan melalui media sosial "Facebook" penulis pribadi dapat dilihat bahwa ada begitu banyak manfaat yang didapatkan melalui penggunaan media sosial "Facebook". Namun meskipun demikian dampak negatif juga tidak dapat dihindarkan.

\section{Dampak Negatif}

Adapun dampak negatif dari penggunaan media sosial "Facebook" menjelang pemilukada Aceh Jaya adalah sebagai berikut:

\section{a. Saling Menyerang antara Pendukung Yah Gam dan Pendukung Irfan TB}

Saling merang dalam hal ini bukanlah secara adu fisik. Namun saling menyerang yang dimaksud adalah adanya saling komentar antara satu pendukung dengan pendukung lainnya. Hal ini terlihat jelas disetiap akun-akun yang digunakan oleh setiap TIM SES. Dalam hal ini, antara satu pihak dengan pihak lainnya saling mencari kelemahan dan kesalahan masing-masing kandidat. 


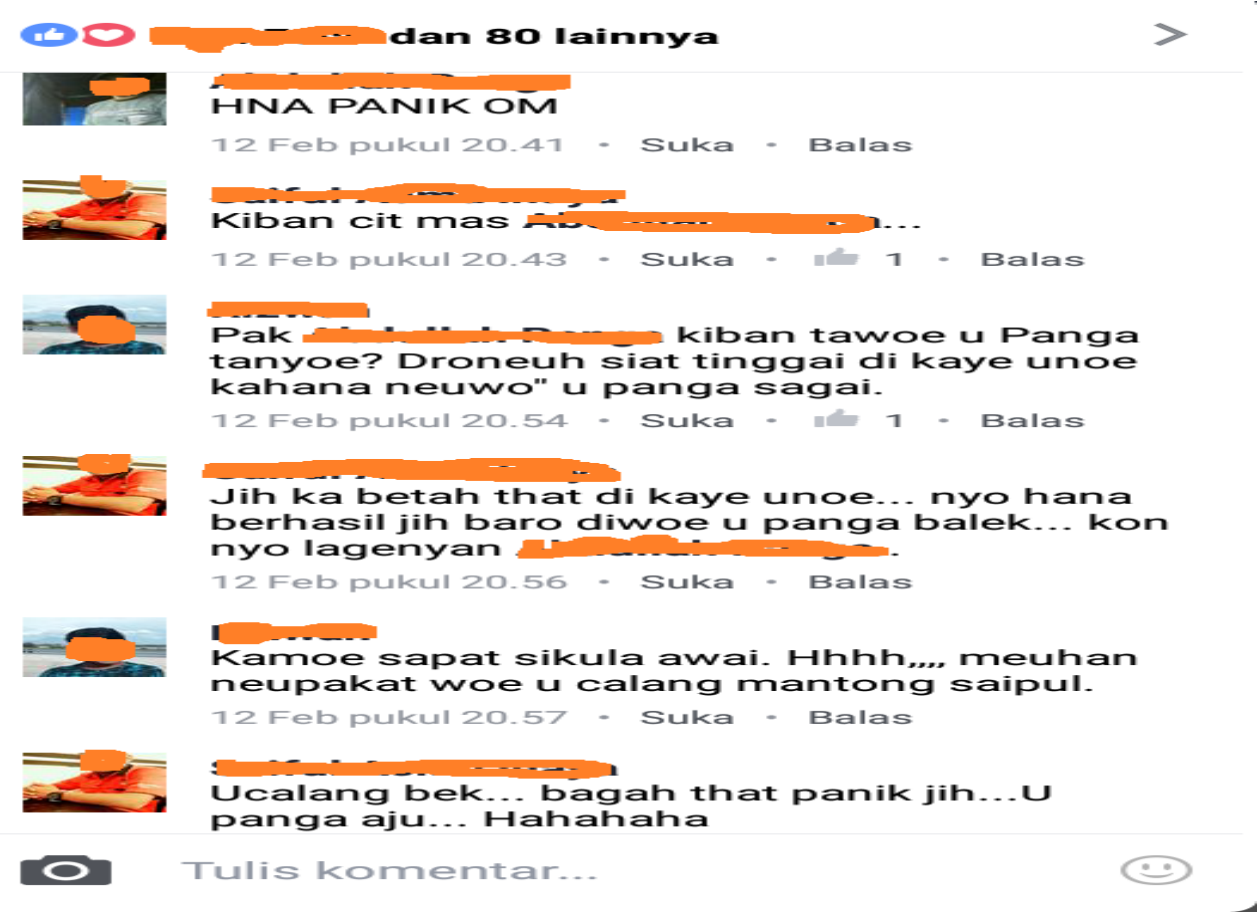

\section{Gambar IX. Saling Menyerang Melalui Media Sosial Facebook}

Dari komentar diatas dapat dilihat bahwa masing-masing simpatisan memberikan komentar mengenai tempat tinggal seorang simpatisan. Hal ini tentu saja berdampak pada kehidupan sehari-harinya dari sang komentator. Dari gambar diatas terlihat jelas bahwa antara satu dengan yang lainnya saling berkomentar dan menyinggung perasaan antara pendukung Irfan TB dengan pendukung Yah Gam.

\section{b. Menjatuhkan Pihak Lawan}

Menjatuhkan pihak lawan dapat dilakukan dengan berbagai cara, salah satunya yaitu dengan memberitakan hal-hal yang ada dilapangan tetapi juga ikut menyertakan kata-kata atau komentar yang kurang etis dilakukan oleh pihak TIM SES dan pihak simpatisan. Penggunaan bahasa yang kurang tepat juga dapat menjatuhkan pihak lawan. Namun dibalik itu pihak lawan juga melakukan hal yang sama yaitu mencari kelemahan dari lawannya. Dengan mendapatkan berbagai isu-isu terkait masing-masing calon, mereka saling memunculkan isu-isu tersebut untuk mempengaruhi pola piker masyarakat agar dapat mendukung para calon yang telah diusung. Hal ini tergantung kepada masyarakat apakah mereka mengikuti isu tersebut atau tidak. Berikut adalah salah satu bentuk komentar yang kurang etis: 


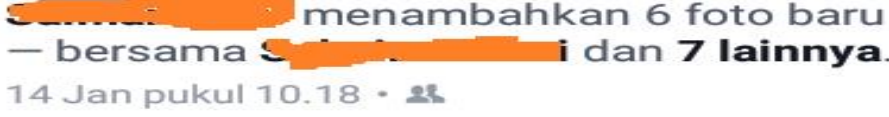

Krueee seumangat ...syedara tanyoe alue jang pasie raya meukuprak mirah ... hana di pajoeh lado basie inoe takoet saket pruet ngoen ciret ... peulom haba aneuk miet hansep umu ngonjeut ciet mariet ngon bahasa sok intelek buet tan.... kita butuh yg berpengalaman bukan yg coba2 keberuntungan...
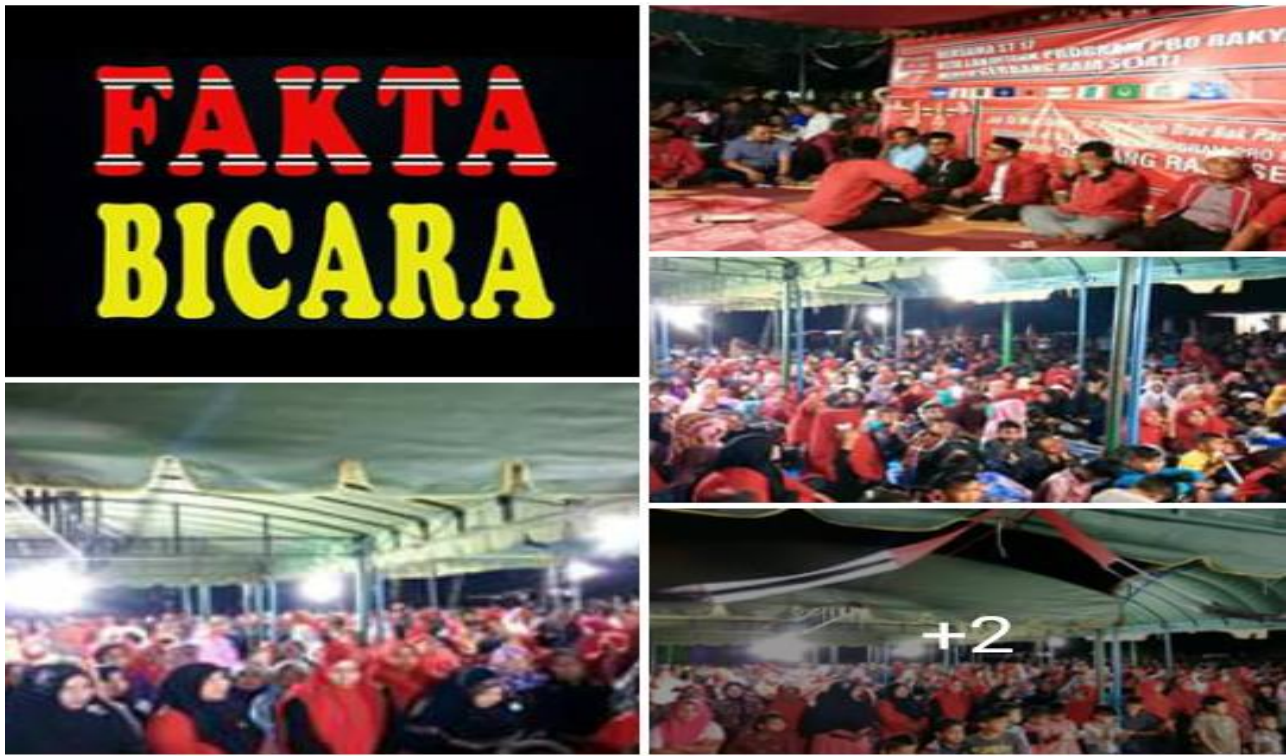

Gambar IX. Menjatuhkan Pihak Lawan Melalui Media Sosial Facebook

Tidak hanya dikalangan Nomor Urut satu yang melakukan hal demikian, namun di Nomor urut dua juga mencari kelemahan lawannya untuk menjatuhkan lawan. Berikut adalah contonya:
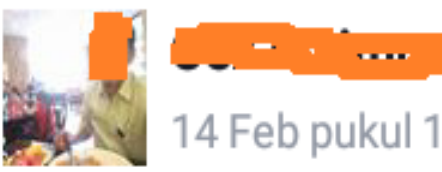

14 Feb pukul 14.58 • Teunom, Aceh Jaya •
"Alhamdulillah.... Mayoritas Pade Ka Kuneng, IsyaAllah Singoh Ta Panen, Cuma simalam teuk Jaga BUY"
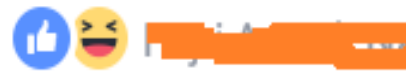

dan 92 lainnya

32 Komentar

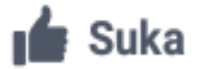

Komentar

\section{Bagikan}

\section{Gambar X. Menjatuhkan Pihak Lawan Melalui Media Sosial Facebook}

Dari gambar diatas terlihat bahwa penggunaan bahasa yang kurang tepat dilayangkan ke publik seharusnya dilakukan penyaringan sehingga tidak terjadi 
saling menjatuhkan antara satu dengan yang lainnya. Meskipun demikian, sampai saat ini, tidak ada pihak yang menggugat terhadap penggunaan kata-kata yang dilontarkan pada masa jelang pemilukada berlangsung. Bahkan hingga pemilukada berakhir tidak ada satu pihak pun yang menggugat tentang hal itu.

\section{Penutup}

Dari uraian di atas dapat disimpulkan bahwa peran media sosial "Facebook" dalam komunikasi politik dalam hal ini media sosial. Media sosial "Facebook" sangat efektif untuk menyampaikan berbagai hal termasuk dalam hal memperkenalkan rekam jejak serta visi dan misi dari sang calon pemimpin Aceh Jaya kedepan. Kampanye yang memanfaatkan jejaring sosial "Facebook" lebih berpengaruh daripada kampanye yang hanya fokus pada penyampaian informasi atau konten saja (dalam artian hanya menggunakan baliho dan kartu namanya saja). Penyebaran perubahan perilaku cenderung terjadi antar teman dekat yang mungkin dibarengi dengan interaksi tatap muka dan membuat diskusi-diskusi dengan berbagai kalangan di dalam kelompok masyarakat. Sehingga lebih efektif dalam melakukan kampanye melalui media sosial "Facebook".

Dalam penggunaan media sosial "Facebook" Dampak merupakan pengaruh kuat yang mendatangkan akibat. Berbicara mengenai dampak, tentuk saja akan ada dampak dari sisi positif dan dampak dari segi negatifnya. Dampak positif dari penggunaan media sosial "Facebook" dalam pemilukada Aceh Jaya yaitu (1) Terjalinnya Tali Persaudaraan Sesama TIM SES dari Masing-masing Pasangan Calon, (2) Dapat Menumbuhkan Partisipasi Masyarakat dalam Berpolitik (3) Memberikan Informasi mengenai Dinamika Pemilukada Kabupaten Aceh Jaya (4) Dapat memperkenalkan Calon Kandidat Kepada Masyarakat (5) Dapat Memperkenalkan Visi dan Misi Calon Kandidat Kepada Masyarakat. adapun dampak negatifnya yaitu (1) Saling Menyerang antara Pendukung Yah Gam dan Pendukung Irfan TB (2) Menjatuhkan Pihak Lawan

\section{Daftar Pustaka:}

Aminah, 2016. Peran Media Dlam Komunikasi Politik Jelang Pemilihan Umum Kepala Daerah Tahun 2017 Di Kabupaten Aceh Barat. Source, Jurnal Ilmu Komunikasi. 2 (3): 175

Antar, Venus. 2004. Manajemen Kampanye; Panduan Teoritis Dan Praktis Dalam Mengefektifkan Kampanye Komunikasi. Bandung: Simbiosa Rekaatam Media

Astrid S. Susanto. 1980. Komunikasi Sosial di Indonesia. Bandung: Bina Cipta.

Cangara, Hafied. 2009. Komunikasi Politik: Konsep, Teori dan Strategi. Jakarta: Rajawali Pers.

Kantaprawira, Rusadi. 1983. Sistem Politik Indonesia: Suatu Model pengantar. Bandung: Sinar Baru

Lubis, 200. Pengantar Komunikasi Lintas budaya. Medan: Universitas Sumatera Utara

Nimmo. 2001. Komunikasi Politik; Khalayak dan Efek, Bandung: Remaja Rosdakarya.

Pawito. 2009. Komunikasi Politik: Media Massa dan Kampanye Pemilihan. Yogyakarta \& Bandung: Jalasutra.

Riswandi. 2009. Ilmu Komunikasi. Jakarta: Graha Ilmu 
Shanon and weaver. 1945. The Mathematical theory of Communication. Urbana:University of Illinois Press 